\title{
The Practice of Online Differentiated Instruction and Its Im- pact on Motivation and Academic Performance in the Wake of Covid-19
}

\author{
Mohd Hasrul Kamarulzaman ${ }^{1 *}$, Melor Md Yunus ${ }^{2}$, Hazita Azman ${ }^{3}$ and Azizah Mohd Zahidi ${ }^{4}$ \\ 1 Language Center, National Defence University of Malaysia, Kem Sungai Besi, 57000 Kuala Lumpur, Malay- \\ sia; hasrul@upnm.edu.my \\ 2 Faculty of Education, Universiti Kebangsaan Malaysia, Selangor 43600, Malaysia; melor@ukm.edu.my \\ 3 Faculty of Social Sciences \& Humanities, Universiti Kebangsaan Malaysia, Selangor 43600, Malaysia; \\ hazita@ukm.edu.my \\ 4 Pusat Genius@Pintar Negara, Universiti Kebangsaan Malaysia, Selangor 43600, Malaysia; \\ deqya@ukm.edu.my \\ * Correspondence: hasrul@upnm.edu.my
}

\begin{abstract}
Differentiated instruction has been implemented in classrooms where students who come from various backgrounds require appropriate lessons that are tailored to their varied learning preferences. As the spread of coronavirus 19 (Covid-19) is becoming more rampant, online learning has been lifted up as the main platform of teaching and learning, forcing the need to shift from the conventional face-to-face classroom to online, or virtual, mode of knowledge transfer. Having such global phenomenon affecting education, how does it affect the implementation of differentiated instruction that has been practised regularly by teachers before the wake of Covid-19? Previous studies have shown how it is done in the normal classroom setting, and that the practice of differentiated instruction contributes to students' motivation as well as academic performance. However, there is a need to explore how do teachers go about with online differentiated instruction and how does it affect the students, since online learning poses various threads to both teachers and students; and thus, one might argue the effectiveness of not only the teaching approach but also the overall teaching and learning outcomes. Borg's framework of teacher cognition, which has been extensively used in exploring how teachers teach, can be utilized to document the practice of online differentiated instruction. This study aimed to explore the practice of online differentiated instruction by teachers and examined its impact on students' motivation and academic performance during the Covid-19 outbreak. The participants of this study consists of 247 gifted students from a public school in Malaysia. To meet these aims, this study employed a mixed method research design, utilizing the framework of teacher cognition to explore the teachers' practice of online differentiated through interviews; and, utilizing a survey design using a questionnaire to determine the impact of online differentiated instruction towards students' motivation and academic performance. The findings revealed that although online differentiated instruction is feasible, however, appropriate combination of differentiation constructs need to be applied in order to achieve higher motivation and better academic performance among the students.
\end{abstract}

Keywords: online teaching and learning; differentiated instruction; gifted students; motivation; achievement; English language teaching

\section{Introduction}

The introduction of the education for the gifted students and differentiated teaching approach in the education system serves to address the diversity issue towards providing equal and flexible education. According to (Chang 1999), the likelihood of learners to be engaged in learning with others who came from varied backgrounds increases as the 
number of population increases. Learners thus are surrounded with peers who have different perspectives or opinions, and especially the ways they process information or knowledge. Learning diversity therefore is inherent in education.

Education encompasses unlimited forms of diversity. Language, age, tradition, gender, ability, disability, interest, talent, heritage, ethnicity and religion are among the many types of differences inherent to every human being that contribute to the diversity in education in general. Such colorful combination of characteristics makes every individual person unique from one to another, unlimited to particular borders of the world. In the schooling context, students are grouped according to different levels and different classrooms or groups. Still, within a particular group of a particular level, learner diversity persists despite streaming procedures imposed during enrollment.

Kauchak \& Eggen (2011) point out that diversity is increasing in today's classroom that consists of students who differ in terms of language, culture, learning styles, abilities, exceptionalities, and gender. In this instance, educators at large should have been acknowledging the fact that students regardless of their grade levels, have different abilities, interests, as well as needs or preferences in learning. Differentiated instruction thus provides the opportunity for teachers to bring students together in a classroom despite their differences (George 2005). In addition, McCoy \& Radar (2007) said that not only differentiation allows for curriculum modification, however, it also provides equal learning opportunity for all learners when their diverse needs are considered upon the learning.

\section{Applying Learner Diversity in Teaching}

Most commonly, cultural backgrounds such as ethnicities, languages, or traditions are the rooting factors that contribute to varying learning abilities, interests, and preferences among the students. Suffice to say that with such dynamic demography of student's background, teaching and learning should be eclectic rather than one direct approach. Simply, teachers should walk into their classrooms with more than one planned strategy to face the various types of students they have. In the era of borderless world, therefore, learners are uniquely diverse that they are in need of diverse teaching and learning strategies that could meet their differences in learning. In this light, Levy (2008) points out that teachers, meeting each student at the level where they are with the aim to develop their growth in education, should utilize differentiated instruction. By embracing the notion of learning diversity, attending to the varying abilities, interests, and needs of the learners, differentiation allows teachers to provide learners with personalized learning since each learner will have equal opportunity to learning.

Learner's background, cultural or language background for example, which is formed through their learned experiences from observation of their surroundings, contribute to varying assumptions, perceptions and interpretations that the learners have over the world, and therefore affected the way knowledge or information is interpreted and understood. (Cifuentes \& Ozel (2006) stated that it is important for teachers to simulate a classroom environment that allows students to comfortably negotiate meaning as they involve in meaningful communication, such as discussion on a common topic. Such socially comforting environment encourages learners to discuss their views on certain idea and motivates them to engage more in a discussion in the effort to improve their understanding.

Consequently, teachers have to face the challenge of preparing lessons that are appropriate to their students, in preparing them for the national standardized curriculum and exams, as well as ensuring the lesson as informative as it is interesting to the students. As a teacher, time is not what they have in irder to conduct studies on differentiation strategies that would benefit their students, and as such, most lessons are unplanned and spontaneous as they stepped into their classroom (White 2013). To make matters worse, the global outbreak of Covid-19 has somehow made the already challenging task of differentiating lesson faced by teachers even more difficult.

The importance of acknowledging and identifying diversity traits among learners allow teachers to apply teaching strategies that would best attend to every learner. Complementary to learner diversity, differentiated instruction represents an honor towards 
learner's diverse backgrounds, as teachers gain the understanding of whom the learners are and how they are different from one another. Yet, the core of differentiated instruction is the need to know and address learner's differences in abilities, interests, and preferences. According to Levy (2008), every teacher indeed had differentiated his or her instruction in one way or another. Levy (2008) listed some differentiation strategies such as allowing more time to complete an assignment, allowing students to choose books to read, and providing different types of assignments, even though not all strategies are responsive to every learner. The most important consideration in a differentiated teaching and learning is that teachers should always be flexible in deciding what is best for their students.

\section{Literature Review}

\subsection{Education Reform: Towards Equal and Flexible Education}

In Malaysia, the issue of learner diversity was addressed in its current Education Blueprint that indicates the country's profound education reform aiming largely towards student's learning outcome. It was introduced by its Education Ministry as a result of increased education standards internationally, the aspiration of the Government of Malaysia to equip its children with necessary skills for the $21^{\text {st }}$ century, and the surging expectations of the public towards the country's education system Malaysia (2013).

With the focus on addressing the issue of diversity, the Malaysia Education Ministry has now put more emphasis on the learner aspect, focusing on providing the right kind of pedagogy for particular groups of learners. In conjunction with the national equity aspiration, the Ministry recognizes that learning environment that can optimize their full potential is necessary, not only for the benefit of the students, but also the country. Thus the Ministry is now acknowledging that gifted students are beneficial for the country's future human capital, and that providing a tailored and flexible education program that caters for the needs of all students is important to maximize their learning potential. This part of education is so crucial that without it could result in Malaysia losing some of its invaluable workforce, thinkers, scientists or technocrats either because they have become school dropouts, or they have migrated to other countries that offer better educational experiences. The country would benefit from such ingenious approach to develop existing potentials of gifted students as future human capital. Studies have shown that students who do not perform in examination might be gifted in their own ways that they require certain instruction (Davis et al. 2011; Goodhew 2009). These students reflect inappropriate classroom experience in attending to their actual intellectual capacity (Crocker 2004; Davis et al. 2011).

Previously, with similar philosophy of developing every student's full potential, "Education in Malaysia is [...] developing the potential of individuals in a holistic and integrated manner, so as to produce individuals who are intellectually, spiritually, emotionally and physically balanced and harmonious..." (Educational Planning and Research Division, 2008, pg. xi). Accordingly, substantial initiatives for students with specific needs (such as the disabled and indigenous/minority groups) have been put forth by the Ministry, but to the exclusion of the gifted group, and the appropriate approach to teaching and learning. The Malaysian Prime Minister, Dato' Sri Mohd Najib Tun Abdul Razak, having acknowledged the importance of the education for the gifted, said this particular group of students "... had been forgotten or left behind in the education system" (Malaysia 2013: pg. Foreword). Therefore, the inclusion of a special education program for the gifted students in the country indicates the Ministry's concern towards moulding the nation's human capital and promoting the growth of national innovation.

In the effort to accentuate the nation's aspiration toward equal learning, the Ministry was cognizant of the factor that would contribute to successful learning outcome i.e. pedagogy. This was manifested through the introduction of differentiated instruction in teaching and learning of English language in the public schools. Tomlinson and Allan (2000) state that through differentiated instruction, teachers provide "... classroom activities 
and tasks that are equally interesting and engaging, as well as provide students with equal access to essential knowledge and skills, regardless of the students' levels".

Therefore, as the result of the educational shift toward addressing the attributes of learner diversity, the Ministry had included into the Malaysia education system the initiative to implement differentiated instruction in the teaching of English language, which reflects one of the system's aspirations i.e. equity. Equity in education conveys the Ministry's aims to minimize the influence of diversity such as cultural, language, socio-economic, urban-rural, and gender factors towards minimizing the gaps in learner achievement, by delivering the highest quality education for every student through any learning tools needed, providing choices and flexibility in educational pathways, and providing equal education opportunities for students of diverse interests and abilities to develop their talents. Equitable education also includes providing greater support, or programs, for diverse groups of students such as special needs students, indigenous and other minority groups, and, the latest one i.e. gifted students, in order to tap their learning potential.

\subsection{Differentiated Instruction}

According to (Blaz 2013) Blaz (2006), the term differentiation surfaced in the 1980s. Differentiation renowned advocate, Tomlinson (1995:3), explained differentiation as in the following:

At its most basic level, differentiating instruction means "shaking up" what goes on in the classroom so that students have multiple options for taking in information, making sense of ideas, and expressing what they learn. In other words, a differentiated classroom provides different avenues to acquiring content, processing or makings of ideas, and to developing products ( $p .3$ ).

Common terms found in the literature had described differentiated instruction as a set of strategies, a belief system, and a process, of teaching and learning that is based on students' needs and preferences (Anderson, Kelly M.; Algozzine, Bob 2007; Levy 2008; Rock et al. 2008; Carol A Tomlinson \& Strickland 2005). Tomlinson (2005) definition has been referred to by most researches i.e. the process of determining what students learn, how they will learn the what, and how will they demonstrate what they have acquired. This definition is reflected in her model of differentiated instruction (Carol Ann Tomlinson 1999) that comprises several constructs i.e. content, process, product, readiness, interest, and learning profile. Recently, differentiated instruction has been regarded as 'a philosophy of teaching' (Knowles 2009; Loeser 2014).

Differentiated instruction has thus been practiced for more than a decade and gained its place in education. Extensive researches have been conducted exploring various areas of differentiated instruction. Numerous aspects of differentiated instruction have been discussed and laid out highlighting the rationales, issues, and findings from substantial researches.

\subsection{The Impact of Differentiated Instruction}

Existing studies on the practice of differentiated instruction have been conducted on numerous academic subjects and different groups of learners revealing varied outcomes especially on the students. Lawrence-Brown (2004) and Tieso (2005) had previously found differentiated instruction as beneficial for gifted students. While Kondor (2007) found a slight increase of student engagement and motivation, Powers (2008) revealed that the use of independent study for gifted learners in the regular classroom promote high motivation among the gifted learners. Some researches on differentiated instruction have demonstrated varying implementation and effect toward gifted students' academic achievement, for example through cluster grouping and independent study project (Brulles \& Winebrenner 2012; Launder 2011). Ruggiero (2012) revealed that students' scores on New York State English Language Arts test were higher after receiving a gifted and talented program. Martin and Pickett (2013) utilized differentiated instruction strategies such as pre-assessment, flexible grouping, and learner interest among gifted math and 
music students, and found that the students perceptions of their engagement and motivation changed positively. In a more recent study, Altintas \& Özdemir (2015)found significant difference of math scores for gifted students who received differentiated instruction while Ann and Sizemore (2015) found that content differentiation is significant in meeting the needs of gifted learners.

Callahan et al. (2003) state that "the preparation of teachers... has traditionally ignored the specific needs of children with above-average potential and demonstrated talents, and, as a result, most teachers in the profession today have had little or no preparation to work effectively with this population in their classroom (pg. 4)." In the United States alone, even though differentiation has been implemented in many schools, at the state and local levels, for more than thirty-years, Marotta-Garcia (2011) however, revealed that teachers still face challenges in their experience of differentiation in "applying theory they have learned in professional development training into practice (pg. ix)." Despite trainings provided for, teachers will not simply become expert as the new knowledge learned takes time to result in appropriate and proper implementation of differentiation, and that continuous practice and support are necessary (Marotta-Garcia 2011).

\subsection{Challenges in Providing Differentiated Teaching and Learning}

In effect, despite having standardized policies as well as available teaching resources and references, the challenge in the implementation of differentiated teaching and learning remains unsolved. The review on teacher surveys pertaining to the implementation of differentiated instruction revealed that teachers were having difficulty in implementing differentiated instruction in their classrooms (Hall 2002; Lee 2001).

Differentiation requires teachers to appropriately equip themselves physically and mentally as prior to stepping into the classroom for curriculum delivery, they need to have student data that include their learning preferences such as readiness, interests, and learning styles, a student portfolio of some sort. The interpretation of such an amount of student data poses a rather challenging task for teachers to come up with an appropriate lesson dubbed as equal i.e. one that would ensure learning for every single student despite the diverse student information gathered; thus, such is the case of differentiated instruction.

Tomlinson (2005) highlighted that differentiated instruction requires extensive and structured staff development programs and takes about a decade of practice in order to see its establishment in a particular institution. She explained that content is brought about by "the relationship between economic, social, personal and environmental displays of power and the needs and the interests of individuals, groups, and societies". In other words, teachers should provide knowledge that is within or slightly beyond students' existing intellectual prowess. In order to deliver the intended knowledge (content), teachers design appropriate strategies (process) that require students to be involved in activities, or tasks, that lead to productive thinking and research skills. Finally, the students' learning is manifested through product, which acts as a mode of communication, as seen in students' presentation for example. This cycle of instructional approach is definitely one that might lead teachers to significant pedagogical challenges.

Thus, even though differentiation has definitely gained its place in the academia, its challenges continue to surface (Rock et al. 2008). According to Tomlinson (2000), despite "all of its purported outcomes, differentiation however is complex to use and difficult to promote in schools" (p.26). Lee (2001) added that the conflict between time and effort contributed to the resistance in school reform toward implementing a new idea or pedagogy. VanSciver (2005:535) asserts that differentiation is complex that it is difficult to implement.

In consequence, schools commonly reported that teachers do not seem to sufficiently differentiate their lessons Tomlinson (2008:1). Williams (2012) conducted an experimental mixed-method study between on differentiated instruction and traditional lecture-based strategies in the teaching of mathematics. The study revealed significant differences on mathematics performance between the students who received differentiated instruction and traditional lecture-based strategies. The qualitative findings of the study also revealed 
inappropriate implementation of differentiation strategies, and suggested the need for continuous professional development and support for the teachers.

Marotta-Garcia (2011) conducted a mixed-method study on the teachers who taught gifted students to find out the type of differentiation and the degree to which the teachers differentiate their instruction in heterogeneous classroom. The study involved a survey followed by classroom observations. The study compared the teachers' reported use of differentiation in the survey and their actual classroom implementation. The study revealed negative relationship between the teachers' report and their classroom implementation. The study reported that despite having the knowledge about differentiation, the teachers were incapable to apply the knowledge and theory into the classroom practice.

In addition, Rock et al. (2008) revealed in a study that teachers' determination to cater for every learner's needs through differentiation was put down due to excessive workload responsibilities, demands for substantial content coverage, and negative classroom behavior (p.34). Similarly, Kiley (2011) echoed that apart from the main teaching job, teachers at the same time received multiple loads of information and work making the effort to establish differentiated instruction as an arduous journey.

\subsection{The Practice of Online Differentiated Instruction in the Wake of Covid-19}

The global outbreak of Covid-19 has impacted all sectors known to existence. In economic sector, almost all business have been forced to shut down. Meanwhile, in education, the pandemic has given any governments of the world no choice but to close all schools and implement online teaching and learning. Since then, online platforms have taken over the conventional classroom teaching and learning.

Now, although online teaching and learning has been around for quite sometime, however, it has not been as essential since the rampant spread of Covid-19. In fact, the wonder of the Internet has changed not one, but many other sectors especially in business and trades. The availability of the Internet has definitely made online teaching and learning possible, but not necessarily preferred. The Internet has merged education and technology into its own niche, providing scholars with vast opportunity to explore and propose the wonders that it poses to both teachers and students. But, is it really so?

Thus far, much has been said and gathered about differentiated instruction and the impacts that it poses, both to the teachers and students. However, little is known of online differentiated instruction in which teachers differentiated their lessons and teach online, while students, learn online. This study thus seeks to examine the impact of the practice of online differentiated instruction during Covid-19 outbreak among the gifted students in Malaysia.

\subsection{Theoretical Underpinning}

\subsubsection{The framework of teacher cognition}

Researches investigating teacher knowledge, beliefs, or perspectives reveal the intertwining usage of the terms whereby some scholars advocate for separate reference between the two notions while others use them together in describing teachers' mental networks related to their experiences in teaching and learning. The result of the inconsistent usage of the terms is the varying models of teacher knowledge and beliefs proposed by the scholars. Consequently, based on extensive meta-analysis of studies investigating language teachers and their teaching practices, Borg (1997) proposes a conceptual and operational framework (Figure 1). According to Borg (2006), the studies comprise "overwhelming array of concepts", or terms, such as knowledge, beliefs, assumptions, etc., in which "the confusion is also due to the fact that identical terms have been defined in different ways and different terms have been used to describe similar concepts (p. 35). 


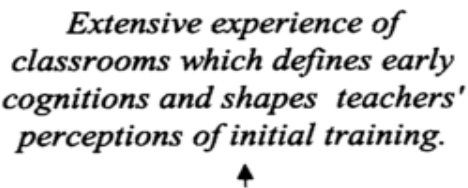

$\mathbf{4}$

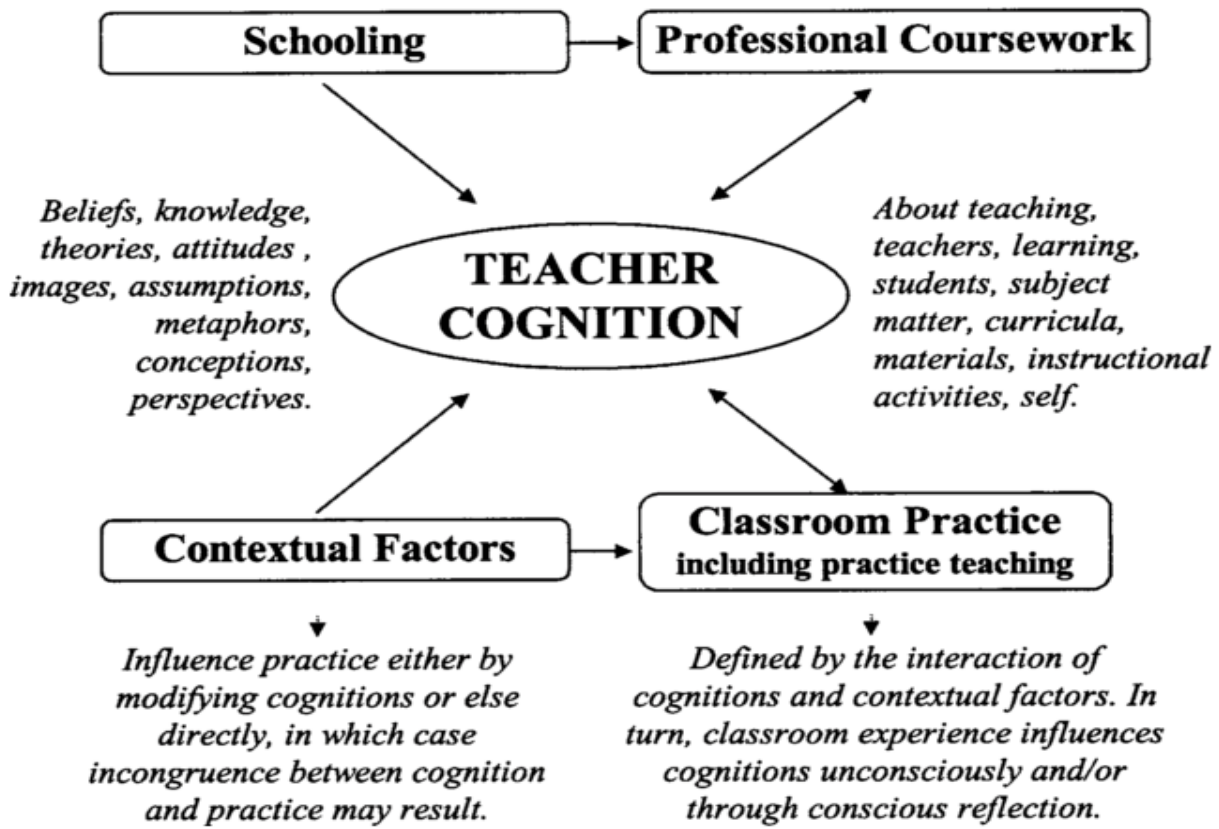

Figure 1. Framework of Teacher Cognition (Borg, 1997).

This framework serves at the macro level of the present study i.e. establishing the constructs understudied. Borg (2003) stated that teacher cognition include among others the knowledge, beliefs, theories, attitudes, images, assumptions, metaphors, conceptions, and perspectives about teaching, teachers, learning, students, subject matter, curricula, materials, instructional activities, and self (p.82). This framework suggests that prior schooling, professional coursework, contextual factors, and classroom experience make up for teacher cognition; and that teacher cognition i.e. what teachers think, believe, and know is related to how teachers teach (p. 81). According to Borg (2009:3), the nature of teacher cognition and its relationship to what teachers do include:

- teacher cognition act as a filter through which teachers interpret new information and experience

- teacher cognition can be deep-rooted and resistant to change

- teacher cognition exert a persistent long-term influence on teachers' instructional practices

- teacher cognition are not always reflected in what teachers do in the classroom

- teacher cognition interact bi-directionally with experience i.e. beliefs influence practices, but practices can also lead to changes in beliefs)

Subsequently, in this study, teachers' knowledge and beliefs are treated/categorized separately but as one construct, using Borg's (1997) term teacher cognition. Despite dismissing the notions of teacher knowledge and teacher beliefs, these terms are used where it is appropriate as delineated by scholars in the existing literature of teacher knowledge and beliefs. Thus, as a whole, this study will investigate a) teacher cognition with regards to their practice of online differentiated instruction, and b) its impact on students' learning outcomes; meanwhile, the review of literature, and presentation and discussion of the findings will display the segregation between teacher knowledge and teacher beliefs, in accordance with the research objectives of the study.

\subsubsection{Model of differentiated instruction}

The teacher cognition framework is complemented by Tomlinson's (1999) model of DI at the micro level of the study. Figure 2 depicts the constructs of DI which provide the 
grounding base for analyzing the data. Tomlinson's model of DI reflects a teacher's response to students' varying learning needs. It explains that a differentiated lesson should be based on on-going assessment and adjustment, allow flexible grouping, and provide respectful tasks. Teacher can differentiate content, proces, or product, according to students' readiness, interest, or learning profile. These constructs provide the references for the researcher in coding the right responses provided by the participants during the data analysis stage.

\section{Differentiation of Instruction}

Is a teacher's response to learners' needs

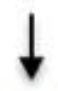

Guided by general principles of differentiation

Respectful tasks

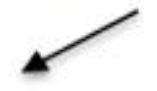

Flexible groupings
Ongoing assessments and adjustments

Teacher can differentiate

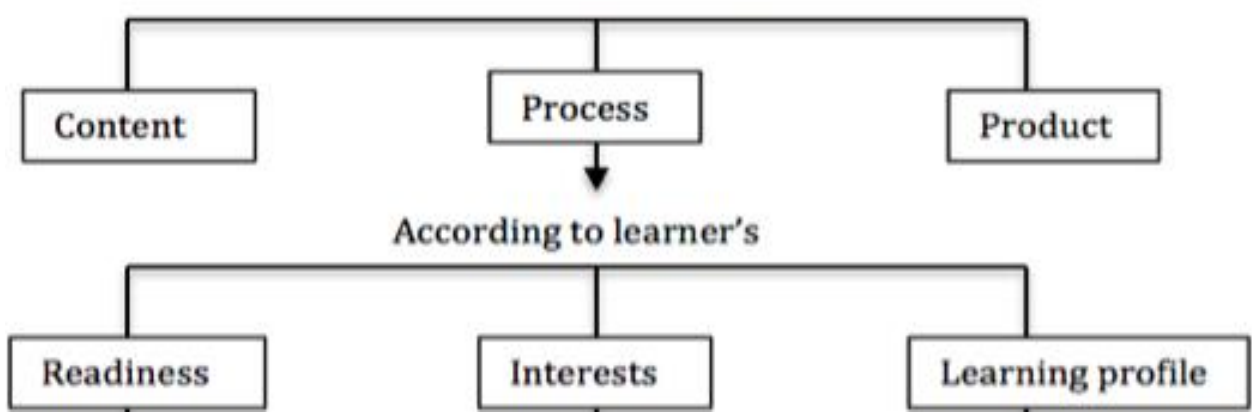

Figure 2. Model of Differentiated Instruction (Tomlinson, 1999).

Combining the social constructivist theory, the framework of teacher cognition developed by Borg, and Tomlinson's model of differentiated instruction, the following operational constructs were identified for the study:

a) Teacher cognition; i.e. teacher knowledge, referring to description of teachers' cognitive principles towards providing a particular instructional approach i.e. of what teachers think, know, or believe about differentiated instruction

b) Differentiated instruction; i.e. differentiation strategies, referring to description of the extent teachers practise differentiated instruction in their classrooms in relation to their knowledge

c) Impact of differentiation; i.e. the extent to which teachers' knowledge and practice of differentiated instruction affect overall teaching practice and their students' learning outcomes, as measured by student motivation and achievement i.e. English language results.

Therefore, Borg's teacher cognition and Tomlinson's model of DI are the fundamentals utilised in exploring teacher cognition of online differentiated instruction in English language teaching and learning (see Figure 3). This theoretical framework guides the investigation into teachers' cognition (e.g. knowledge, beliefs, perceptions) in employing their DI strategies, and its impact on both the teachers and students. 


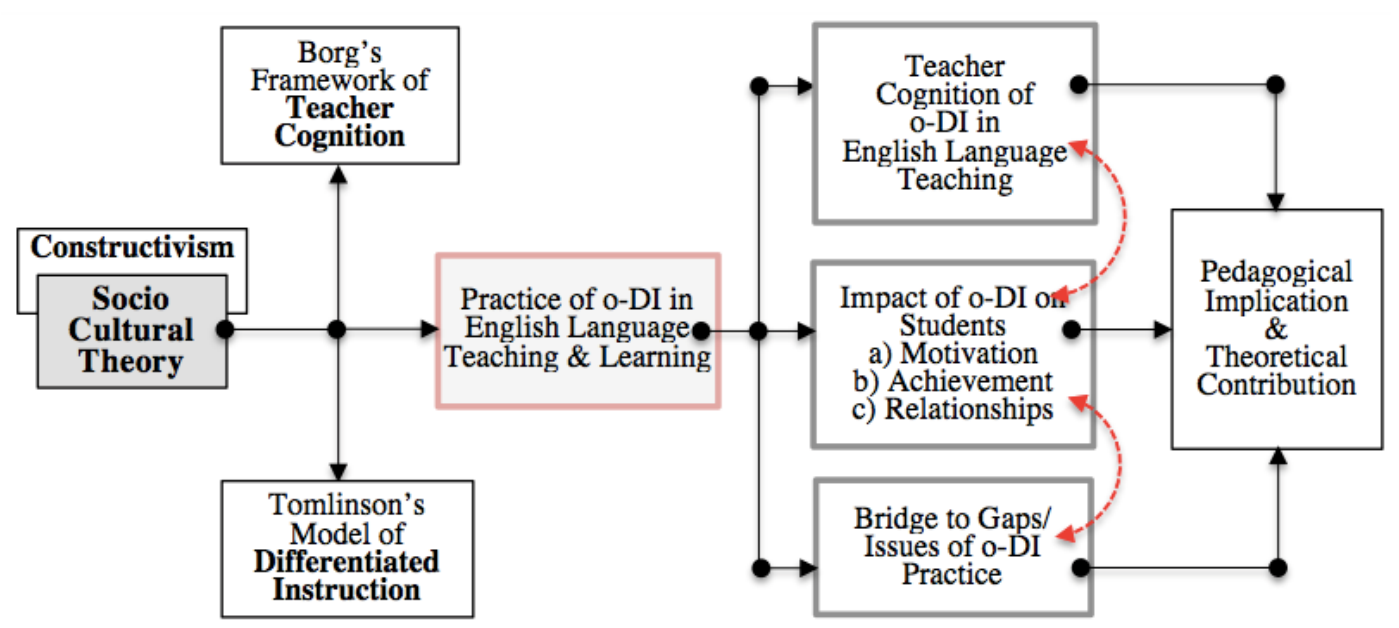

Figure 3. Theoretical Framework Exploring Teacher Cognition of Online Differentiated Instruction in English Language Teaching.

\subsection{The Present Study}

Undoubtedly, Covid-19 has changed the nature of education. The Internet, together with technology, introduce online teaching and learning as the main medium that ensures, if at all, the very existence of education. The review of literature reveals that teachers certainly faced challenges while implementing differentiated instruction in the conventional classrooms. Nevertheless, the implementation of differentiated instruction contributes positively to the students. However, how do the teachers differentiate lessons for online teaching and learning, and how does online differentiated teaching and learning affect the students motivationally and academically?

Based on the theoretical framework above, researchers can postulate that teachers possess specific knowledge about online differentiated instruction (Teacher Cognition of o-DI in ELT), from which such teacher cognition determines their online teaching/classroom practice, and that this online differentiated teaching practice, in return, influences students' learning outcomes (Impact of o-DI on Students i.e. motivation and academic performance). The present study therefore seeks to provide answers to how has online differentiated instruction impacted students' learning outcomes. This research questions are:

a) To what extend has online differentiated instruction impacted student motivation during Covid-19 outbreak?

b) To what extend has student motivation impacted their academic performance during Covid-19 outbreak?

c) What is the relationship between online differentiated instruction and student motivation

\section{Methodology}

\subsection{Research Design}

This study employed a survey research design, utilizing a questionnaire that measures students' motivational orientation towards online differentiated teaching and learning during Covid-19. The data from the survey were keyed in into SPSS V.20 and computed quantitatively for the results.

\subsection{Participants}

This study was conducted at one public school in Malaysia. This school is Malaysia's only school for the gifted students that practise differentiated instruction in teaching and learning. The participants thus were purposively selected because it is the only school with teachers who implement differentiated instruction in their teaching, and students 
who received differentiated learning. Differentiated instruction is implemented for all students and for all courses offered at the school. These include Malay Language, English, Mathematics, Physics, Chemistry, Biology, History, and Islamic Education. For the purpose of this research, data were gathered only fromEnglish Language teaching and learning implemented during the pandemic period. A total of 247 students took the survey. The demographics of the students are shown in Table 1 below.

Table 1. Demographic Statistics of the Students' Participants.

\begin{tabular}{|c|c|c|c|}
\hline $\begin{array}{l}\text { Participants' In- } \\
\text { formation }\end{array}$ & Categories & $N$ & Percentage \\
\hline \multirow{2}{*}{ Teachers } & Teacher 1 & 128 & 51.8 \\
\hline & Teacher 2 & 119 & 48.2 \\
\hline Total & 2 & 247 & 100.0 \\
\hline \multirow{2}{*}{ Students } & Male & 124 & 50.2 \\
\hline & Female & 123 & 49.8 \\
\hline Total & & 247 & 100.0 \\
\hline \multirow{4}{*}{ Levels } & Form 1 & 44 & 17.8 \\
\hline & Form 2 & 68 & 27.5 \\
\hline & Form 4 & 60 & 24.3 \\
\hline & Form 5 & 75 & 30.4 \\
\hline Total & & 247 & 100.0 \\
\hline \multirow{8}{*}{$\begin{array}{l}\text { The students' } \\
\text { English } \\
\text { Language test } \\
\text { results }\end{array}$} & $\mathrm{A}+$ & 12 & 4.9 \\
\hline & A & 80 & 32.4 \\
\hline & A- & 93 & 37.7 \\
\hline & $\mathrm{B}+$ & 37 & 15.0 \\
\hline & B & 15 & 6.1 \\
\hline & B- & 7 & 2.8 \\
\hline & $\mathrm{C}+$ & 1 & 0.4 \\
\hline & $\mathrm{C}$ & 2 & 0.8 \\
\hline Total & & 247 & 100.0 \\
\hline
\end{tabular}

\subsection{Instrument}

The data of this research were derived from two sources: questionnaire and students' English language test results. The questionnaire, comprising 68 items, measures the motivational orientation of students towards online differentiated instruction that they experience during the outbreak of Covid-19. The questionnaire contains nine categories (Table ) namely content, process, product, readiness, interest, learning profile, grouping, assess and adjust, and teacher's roles, referred to as Motivational Orientations of DI in English Language Teaching (MoDiELT). Researchers and practitioners may contact author for a copy of MoDieLT.

The instrument was validated for construct validity, factor analysis, and reliability estimates. After the validation process, the questionnaires were distributed to the students; meanwhile, their English language test results were obtained from the administrator's office. The scores from the questionnaire and their English language test were keyed into SPPS V20. 
The reliability of the questionnaire was computed to examine the internal consistency and correlation coefficient of the items in each category of MoDiELT as indicated by the cronbach's alpha values. The alpha values revealed in the Table 2 below indicate that the instrument has a high degree of reliability, with overall value of 0.944 . Meanwhile, the overall means reveal high to very high correlation coefficent, at significance value of $\mathrm{p}<0.01$.

Table 2. MoDiELT and its Reliability Values.

\begin{tabular}{ccccc}
\hline MoDiELT & No. of Items & $\begin{array}{c}\text { Cronbach's } \\
\text { Alpha }\end{array}$ & $\begin{array}{c}\text { Overall Means of } \\
\text { Correlation Coefficient }\end{array}$ & Strength \\
\hline Interest & 5 & 0.679 & $.747^{* *}$ & Very High \\
\hline Readiness & 10 & 0.793 & $.758^{* *}$ & Very High \\
\hline Learning Profile & 13 & 0.864 & $.797^{* *}$ & Very High \\
\hline Teacher's Roles & 8 & 0.788 & $.710^{* *}$ & Very High \\
\hline Content & 7 & 0.764 & $.731^{* *}$ & Very High \\
\hline Process & 6 & 0.708 & $.790^{* *}$ & Very High \\
\hline Grouping & 7 & 0.628 & $.571^{* *}$ & High \\
\hline Product & 6 & 0.694 & $.731^{* *}$ & Very High \\
\hline Assess \& Adjust & 6 & 0.640 & $.742^{* *}$ & Very High \\
\hline Overall & $\mathbf{6 8}$ & $\mathbf{0 . 9 4 4}$ & & \\
\hline
\end{tabular}

\subsection{Subsec}

\subsection{Data Collection and Analyses}

Due to the movement control order imposed by the government through out the country, this research utilized an online-based data collection procedure. The questionnaire was made online utilizing Google Forms questionnaire platform. The link to this online questionnaire was shared via email as well as through social media application i.e. WhatsApp.

Descriptive analyses furnish this section with the statistical information of the student participants involved, and the overall motivation and achievement of the students. Further analyses looking into the differences of the students' motivation and achievement according to their respective teachers (Teacher 1 and 2) and students' levels (Form 1, 2, 4, and 5), are also presented and discussed. These include inferential analyses which are ttest analysis for the former while One-Way ANOVA with post-hoc Tukey HSD test for the latter. Finally, Pearson correlation coefficient was utilized to determine the extent to which online differentiated instruction is associated with student motivation and their academic performance.

The following sections discuss the overall quantitative findings about students' motivational orientation towards online differentiated instruction in relation to the students' academic achievement.

\section{Findings and Discussion}

\subsection{To what extend has online differentiated instruction impacted student motivation during Covid-19 outbreak?}

This section presents and discusses the impact of online differentiated instruction on student motivation. Table 3 below displays the percentage of the students' overall scores on each construct of MoDiELT ranging from low, moderate, to high. The analysis reveals that most students were highly motivated towards differentiated English language teaching as shown in interest with 169 students $(68.4 \%)$, readiness with 136 students (55.1\%), teacher's roles with 209 students (84.6\%), content with 167 students $(67.6 \%)$, process with 172 students (69.6\%), grouping with 151 students (61.1\%) and assessment/adjustment with 140 students $(56.7 \%)$. However, product and learning profile 
were moderately motivating for the students with 142 students (57.5\%) and 125 students (50.6\%) respectively.

Table 3. Students' Scores on MoDiELT.

\begin{tabular}{lccc}
\hline MoDiELT & Low & Moderate & High \\
\hline Interest & $0(0.0 \%)$ & $78(31.6 \%)$ & $169(68.4 \%)$ \\
\hline Readiness & $2(0.8 \%)$ & $109(44.1 \%)$ & $136(55.1 \%)$ \\
\hline Lprofile & $1(0.4 \%)$ & $125(50.6 \%)$ & $121(49.0 \%)$ \\
\hline Troles & $0(0.0 \%)$ & $38(15.4 \%)$ & $209(84.6 \%)$ \\
\hline Content & $3(1.2 \%)$ & $77(31.2 \%)$ & $167(67.6 \%)$ \\
\hline Process & $2(0.8 \%)$ & $73(29.6 \%)$ & $172(69.6 \%)$ \\
\hline Grouping & $3(1.2 \%)$ & $93(37.7 \%)$ & $151(61.1 \%)$ \\
\hline Product & $11(4.5 \%)$ & $142(57.5 \%)$ & $94(38.1 \%)$ \\
\hline Asses_adjus & $2(0.8 \%)$ & $105(42.5 \%)$ & $140(56.7 \%)$ \\
\hline
\end{tabular}

Next, the means and standard deviation of the students' scores on MoDiELT were calculated. Table 4 below shows the overall means and standard deviation of each construct of MoDiELT. It was revealed that teacher's roles was the most significant construct of MoDiELT with the mean score of 4.171 , std.dev. $=0.473$. This is followed with interest (mean=3.935, std.dev. $=.502)$, content (mean=3.882, std.dev. $=0.573)$, process (mean=3.835, std.dev. $=0.581)$, grouping $\quad($ mean $=3.769$, std.dev. $=0.555)$, readiness (mean=3.696, std.dev. $=0.446)$, assessment/adjustment $\quad($ mean $=3.695$, std.dev. $=0.564)$, learning profile (mean $=3.639$, std.dev. $=0.497$ ) and product (mean $=3.424$, std.dev. $=0.552$ ).

Table 4. Overall Means and Standard Deviations.

\begin{tabular}{lll}
\hline $\begin{array}{l}\text { Motivational constructs } \\
\text { on MoDiELT }\end{array}$ & Mean & Std. Deviation \\
\hline Interest & 3.935 & 0.502 \\
\hline Readiness & 3.696 & 0.446 \\
\hline LProfile & 3.639 & 0.497 \\
\hline Troles & $\mathbf{4 . 1 7 1}$ & 0.473 \\
\hline Content & 3.882 & 0.573 \\
\hline Process & 3.835 & 0.581 \\
\hline FGrouping & 3.769 & 0.555 \\
\hline Product & 3.424 & 0.552 \\
\hline Assess_Adjust & 3.695 & 0.564 \\
\hline
\end{tabular}

This section has presented the overall results of the students' scores on MoDiELT, revealing their motivation towards differentiated English language teaching. The analysis concludes that, in overall, the students were highly motivated towards differentiated English language teaching. This finding reveals that teacher's roles is the most significant construct of MoDiELT. This suggests that the students' motivation was mostly influenced by teacher's roles, and as such, a very important determinant in differentiated English language teaching and learning.

Thus, in addition to the constructs of differentiated instruction as outlined by Tomlinson's, the present study proposes that teachers should have appropriate knowledge about their roles in providing differentiated lessons. As revealed in the teacher cognition of DI section earlier, the roles of a differentiation teacher is a manager who continuously assesses their students, and adjusts lessons accordingly, in order to provide choices in learning; and, who provides appropriate facilitation during the learning process, by constant monitoring and motivating the students, towards achieving 
successful differentiated English language teaching. In the following sections, detailed account of the students' scores on MoDiELT is presented in relation to their respective levels (Form 1, 2, 4 and 5) and teachers.

\subsubsection{Student Motivation according to Levels (Form 1, 2, 4 and 5)}

This section discusses the students' scores on MoDiELT based on their respective levels i.e. Form 1, Form 2, Form 4, and Form 5. The analysis indicates how the students from each level differ in their motivation towards differentiated English language teaching and learning. In order to find out students' motivation according to levels, OneWay ANOVA test was performed, followed with the post-hoc Tukey HSD test.

The result of One-Way ANOVA indicates that only five constructs of MoDiELT had significant mean difference i.e. interest $F(3,243)=3.803$, $p<0.05$; lprofile $F(3,243)=7.748$, $\mathrm{p}<0.001$; teacher's roles $\mathrm{F}(3,243)=5.185, \mathrm{p}<0.05$; content $\mathrm{F}(3,243)=6.631, \mathrm{p}<0.001$; and product $F(3,243)=3.355, p<0.05$. Meanwhile, the other constructs had no significant mean difference, as shown in readiness $\mathrm{F}(3,243)=.687, \mathrm{p}>0.05$, process $\mathrm{F}(3,243)=2.280, \mathrm{p}>0.05$, fgrouping $F(3,243)=1.003, p>0.05$ and assess \& adjust $F(3,243)=1.454, p>0.05$. Then, a posthoc Tukey HSD test was performed on these five motivational constructs of differentiated instruction that had significant mean difference to identify the mean difference between the groups of students in each level.

The result of the post-hoc Tukey HSD test confirms that there is significant mean difference, $\mathrm{p}<0.05$ (marked with ${ }^{*}$ ), in interest, lprofile, teacher's roles, content and, product. Next, the mean differences and standard deviation for the five constructs of MoDiELT were calculated.

Table 5. Mean Differences and Standard Deviation based on. the Post-Hoc Tukey Test

\begin{tabular}{|c|c|c|c|c|}
\hline $\begin{array}{l}\text { MoDiELT } \\
\text { Constructs }\end{array}$ & Levels & $\mathbf{N}$ & Mean & Std. Dev \\
\hline Interest & $\begin{array}{l}\text { Form 1 } \\
\text { Form } 2 \\
\text { Form } 4 \\
\text { Form } 5 \\
\text { Total }\end{array}$ & $\begin{array}{l}44 \\
\mathbf{6 8} \\
\mathbf{6 0} \\
75 \\
247 \\
\end{array}$ & $\begin{array}{l}3.8591 \\
\mathbf{4 . 0 2 6 5} \\
\mathbf{4 . 0 4 6 7} \\
3.8080 \\
3.9352 \\
\end{array}$ & $\begin{array}{l}.57154 \\
. \mathbf{4 9 1 0 0} \\
. \mathbf{4 1 0 6 5} \\
.50771 \\
.50204 \\
\end{array}$ \\
\hline $\begin{array}{l}\text { Learning } \\
\text { Profile }\end{array}$ & $\begin{array}{l}\text { Form } 1 \\
\text { Form } 2 \\
\text { Form } 4 \\
\text { Form } 5 \\
\text { Total }\end{array}$ & $\begin{array}{l}44 \\
\mathbf{6 8} \\
\mathbf{6 0} \\
75 \\
247 \\
\end{array}$ & $\begin{array}{l}3.4202 \\
\mathbf{3 . 7 9 9 8} \\
\mathbf{3 . 7 4 3 4} \\
3.5364 \\
3.6385 \\
\end{array}$ & $\begin{array}{l}.52697 \\
.51010 \\
.38382 \\
.48518 \\
.49712 \\
\end{array}$ \\
\hline $\begin{array}{l}\text { Teacher's } \\
\text { Roles }\end{array}$ & $\begin{array}{l}\text { Form } 1 \\
\text { Form } 2 \\
\text { Form } 4 \\
\text { Form } 5 \\
\text { Total }\end{array}$ & $\begin{array}{l}44 \\
\mathbf{6 8} \\
\mathbf{6 0} \\
75 \\
247\end{array}$ & $\begin{array}{l}4.1392 \\
\mathbf{4 . 2 9 9 6} \\
\mathbf{4 . 2 4 3 8} \\
4.0150 \\
4.1711 \\
\end{array}$ & $\begin{array}{l}.42042 \\
. \mathbf{4 5 3 6 0} \\
. \mathbf{4 0 7 4 4} \\
.52712 \\
.47307\end{array}$ \\
\hline Content & $\begin{array}{l}\text { Form } 1 \\
\text { Form } 2 \\
\text { Form } 4 \\
\text { Form } 5 \\
\text { Total }\end{array}$ & $\begin{array}{l}44 \\
\mathbf{6 8} \\
\mathbf{6 0} \\
75 \\
247\end{array}$ & $\begin{array}{l}3.7468 \\
\mathbf{4 . 0 6 3 0} \\
\mathbf{3 . 9 9 5 2} \\
3.7067 \\
3.8820\end{array}$ & $\begin{array}{l}.59572 \\
. \mathbf{5 8 5 3 2} \\
. \mathbf{5 0 9 3 2} \\
.53395 \\
.57284\end{array}$ \\
\hline Product & $\begin{array}{l}\text { Form } 1 \\
\text { Form } 2 \\
\text { Form } 4 \\
\text { Form } 5 \\
\text { Total }\end{array}$ & $\begin{array}{l}44 \\
68 \\
60 \\
\mathbf{7 5} \\
247\end{array}$ & $\begin{array}{l}3.4848 \\
3.4632 \\
3.5361 \\
\mathbf{3 . 2 6 2 2} \\
3.4238\end{array}$ & $\begin{array}{l}.62652 \\
.52298 \\
.47942 \\
. \mathbf{5 6 0 9 8} \\
.55229\end{array}$ \\
\hline
\end{tabular}

Based on the calculation of the mean differences and standard deviation in Table 5 above, the overall analysis reveals mixed results of students' motivation towards online differentiated English language teaching according to levels, as summarized here. Meanwhile, take note that Form 1 and 2 students were taught by Teacher 1, while Form 4 and 5 Teacher 2. 
First of all, with regards to MoDiELT construct interest, there is a significant mean difference in student motivation towards online differentiated English language teaching between Form 2 students (mean=4.0265, SD=.49100) and Form 5 students (mean=3.8080, $\mathrm{SD}=.50771$ ); and, Form 4 students (mean=4.0467, $\mathrm{SD}=.41065$ ) and Form 5 students (mean=3.8080, SD=.50771). This suggests that Form 2, Form 4 and Form 5 students had higher motivation in terms of differentiation based on interest. Thus, it can be inferred that online differentiation based on interest by both Teacher 1 and Teacher 2 were appropriate for Form 2, 4, and 5 students.

With regards to learning profile, there is a significant mean difference in student motivation towards differentiated English language teaching between Form 2 students (mean=3.7998, SD=.51010) and Form 1 students (mean=3.4202, SD=.52697); Form 2 (mean=3.7998, SD=.51010) and Form 5 students (mean=3.5364, SD=.48518); and, Form 4 students (mean=3.7434, $\mathrm{SD}=.38382$ ) and Form 1 students (mean=3.4202, $\mathrm{SD}=.52697$ ). This reveals that the students from all levels had high motivation in terms of online differentiation based on learning profile. Thus, it can be deduced that online differentiation based on learning profile provided by both Teacher 1 and Teacher 2 were appropriate for all of the students.

Next, for teacher's roles, there is a significant mean difference in student motivation towards differentiated English language teaching with regards to teacher's roles between: Form 2 students (mean=4.2996, SD=.45360) and Form 5 students (mean=4.0150, $\mathrm{SD}=.52712$ ); and, Form 4 students (mean=4.2438, SD=.40744) and Form 5 students (mean=4.0150, SD=.52712). This reveals that the students from Form 2, Form 4 and Form 5 had high motivation towards the roles of the teachers. Thus, it can be inferred that Teacher 1 and Teacher 2 ' roles in providing online differentiated lessons were appropriate for the students from these levels.

With regards to MoDiELT construct content, there is a significant mean difference in student motivation towards differentiated English language teaching between: Form 2 students (mean=4.0630, SD=.58532) and Form 1 students (mean=3.7468, SD=.59572); Form 2 students (mean=4.0630, $\mathrm{SD}=.58532$ ) and Form 5 students (mean=3.7067, $\mathrm{SD}=.53395$ ); and, Form 4 students (mean=3.9952, $\mathrm{SD}=.50932$ ) and Form 5 students (mean=3.7067, SD=.53395). This reveals that the students from all levels had high motivation in terms of content differentiation. Thus, it can be deduced that content differentiation provided by both Teacher 1 and Teacher 2 was appropriate for all of the students.

Finally, for product, there is a significant mean difference in student motivation towards differentiated English language teaching between Form 4 students (mean=3.5361, $\mathrm{SD}=.47942$ ) and Form 5 students (mean=3.2622, $\mathrm{SD}=.56098$ ). This reveals that the students from Form 4 and Form 5 had high motivation in terms of product differentiation. Thus, it can be inferred that product differentiation provided by Teacher 2 was appropriate for all of the students that she taught (i.e. Form 4 and 5).

\subsubsection{Student Motivation according to Teachers}

This section discusses the students' scores on MoDiELT based on their respective teachers i.e. Teacher 1 and Teacher 2 , in order to see the differences. It shoud be noted that Teacher 1 teaches L1 and L2, while Teacher 2 teaches L4 and L5. Thus, the analysis will indicate to what extent does Teacher 1 and Teacher 2's differentiation practice influence the motivation of their respective students. The inferential analysis used is t-test.

The results of the t-test in Table 6 below shows that there is a significant mean difference in the motivation of the students taught by Teacher 1 and Teacher 2 as shown in content $\mathrm{t}=4.402, \mathrm{p}<0.001$, product $\mathrm{t}=2.190$, interest $\mathrm{t}=3.337, \mathrm{p}<0.05$, lprofile $\mathrm{t}=4.599, \mathrm{p}<0.001$, $\mathrm{p}<0.05$, assess \& adjust $\mathrm{t}=2.016, \mathrm{p}<0.05$, and troles $\mathrm{t}=3.613, \mathrm{p}<0.001$. However, the motivational constructs process, grouping, and readiness did not show any significant mean difference.

Table 6. Result of t-test on MoDiELT constructs between Teacher 1 and Teacher 2. 


\begin{tabular}{|c|c|c|c|c|c|}
\hline & Teacher & $\overline{\mathbf{N}}$ & Mean & Std. Deviation & $t$ \\
\hline \multirow{2}{*}{ Interest } & Teacher 1 & 128 & 4.0359 & .45346 & $3.337^{*}$ \\
\hline & Teacher 2 & 119 & 3.8269 & .53038 & \\
\hline \multirow[t]{2}{*}{ Readiness } & Teacher 1 & 128 & 3.7289 & .41548 & 1.191 \\
\hline & Teacher 2 & 119 & 3.6613 & .47534 & \\
\hline \multirow[t]{2}{*}{ LProfile } & Teacher 1 & 128 & 3.7733 & .45443 & $4.599^{* *}$ \\
\hline & Teacher 2 & 119 & 3.4934 & .50199 & \\
\hline \multirow[t]{2}{*}{ Troles } & Teacher 1 & 128 & 4.2734 & .43180 & $3.613^{* *}$ \\
\hline & Teacher 2 & 119 & 4.0609 & .49222 & \\
\hline \multirow[t]{2}{*}{ Content } & Teacher 1 & 128 & 4.0312 & .54991 & $4.402^{* *}$ \\
\hline & Teacher 2 & 119 & 3.7215 & .55542 & \\
\hline \multirow[t]{2}{*}{ Process } & Teacher 1 & 128 & 3.8802 & .53730 & 1.259 \\
\hline & Teacher 2 & 119 & 3.7871 & .62396 & \\
\hline \multirow[t]{2}{*}{ Grouping } & Teacher 1 & 128 & 3.8058 & .52931 & 1.075 \\
\hline & Teacher 2 & 119 & 3.7299 & .58037 & \\
\hline \multirow[t]{2}{*}{ Product } & Teacher 1 & 128 & 3.4974 & .50239 & $2.190^{*}$ \\
\hline & Teacher 2 & 119 & 3.3445 & .59333 & \\
\hline \multirow{2}{*}{$\begin{array}{l}\text { Assess } \\
\text { Adjustment }\end{array}$} & Teacher 1 & 128 & 3.7643 & .56993 & $2.016^{*}$ \\
\hline & Teacher 2 & 119 & 3.6204 & .55018 & \\
\hline
\end{tabular}

In general, this section reveals that the students were highly motivated towards online differentiated English language teaching. Specifically, the analysis shows that teacher's roles contributed the most to student motivation.

Table 6 above reveals that students taught by Teacher 1 scored higher on the MoDiELT constructs interest, lprofile, troles, content, product and assess \& adjust compared to the students taught by Teacher 2 . This suggests that Teacher 1's students had higher motivation towards her online differentiated lesson, and it can be inferred that Teacher 1 provides the more appropriate online differentiated lessons compared to Teacher 2.

This finding suggests that i) both Teacher 1 and 2's emphasis of online differentiation is significant in content, product, interest, lprofile, assess \& adjust, and troles, and that their emphasis may vary; subsequently, ii) the teachers should revisit their lesson planning for process, grouping, and their knowledge about students' readiness.

\subsection{To what extend has online differentiated instruction impacted students' academic performance during Covid-19 outbreak?}

This section discusses the extent to which online differentiated instruction contribute to students' academic performance based on their achievement in English language test. For this purpose, multiple regression analysis was conducted to learn about the strength of the effect of the students' scores on MoDiELT constructs has against their English language test results. The finding from this analysis thus indicates whether or not online differentiated English language teaching and learning had any effect on student achievement. For this particular investigation, the researcher postulates that students' motivation towards online differentiated instruction has significant influence on their achievement. Thus, Ho: Students' motivation towards online differentiated instruction does not influence their achievement.

Multiple regression analysis was conducted to predict the causal relationship between the students' motivation and their achievement, i.e. the value of the dependent variable [student achievement] based on the value of the independent variable [student motivation]. The result of multiple regression analysis in Table 7 below reveals that all of the MoDiELT constructs contribute to students' English language test results. In overall, MoDiELT constructs predict student achievement significantly at $\mathrm{R}^{2}=0.104, \mathrm{~F}(9,237)=3.058$, $\mathrm{p}<0.05$, and contribute approximately $10.4 \%$ variance to student achievement. The $\mathrm{H}_{0}$ was rejected, thus accepting the notion that students' motivation towards online differentiated instruction has significant influence on student achievement.

Table 7. Multiple Regression Analysis of Students' Scores on MoDiELT. and English Language Test Results.

\begin{tabular}{lllll}
\hline $\begin{array}{l}\text { MoDiELT } \\
\text { [predictors/Ind.Var] }\end{array}$ & B & Beta & T & Sig. \\
\hline
\end{tabular}




\begin{tabular}{lcccc}
\hline Interest & .142 & .060 & .650 & .516 \\
\hline Readiness & -.958 & -.356 & -4.053 & .000 \\
\hline LProfile & .644 & .267 & 2.521 & .012 \\
\hline Troles & .302 & .119 & 1.522 & .129 \\
\hline Content & -.299 & -.143 & -1.518 & .130 \\
\hline Process & -.176 & -.085 & -.890 & .375 \\
\hline FGrouping & .218 & .101 & 1.281 & .201 \\
\hline Product & .119 & .055 & .600 & .549 \\
\hline Assess_Adjus & -.218 & -.102 & -1.126 & .261 \\
\hline $\mathrm{R}^{2}=0.104$ & & & $\mathrm{~F}(9,237)=3.058, \mathrm{p}<0.05$
\end{tabular}

Further analysis indicated that MoDiELT constructs that most significantly predict student achievement are readiness (Beta $=-0.356, \mathrm{t}=-4.053, \mathrm{p}<0.001$ ); and learning profile (Beta=0.267, $\mathrm{t}=2.521, \mathrm{p}<0.05)$. Thus, although this analysis appears to suggest significant influence on student achievement, however, it is not sufficient to make conclusive remark about the relationship since only two out of nine MoDiELT constructs were found to be the highest predictors to student achievement i.e. readiness and learning profile. Thus, further analysis was conducted to determine the relationship between the students' motivation towards online differentiated instruction and their English language results, as described in the next section.

\subsection{What is the relationship between students' motivation towards online differentiated instruction and academic performance?}

Based on the analyses of the students' scores on MoDiELT constructs, the previous two sections have revealed the impact of online differentiated instruction on student motivation (section 3.5.1) and academic performance (section 3.5.2), indicating the influence of online differentiated instruction provided by both Teacher 1 and Teacher 2 . The findings provide the researcher with the bases to examine further the relationship between the two variables. At this juncture, the researcher postulates that there is a significant relationship between student motivation and academic performance in relation to online differentiated English language teaching and learning; thus, $\mathrm{H}_{0}=$ There is no significant relationship between student motivation and academic performance.

Inferential analysis was conducted utilizing Pearson's correlation coefficient in order to examine the association between the two variables. This analysis reveals whether a relationship exists between student motivation and academic performance, the strength of the relationship, and whether the relationship is positive or negative. Table 8 below displays the correlation between student motivation and academic performance based on the students' scores on MoDiELT and their achievement in English language test.

Table 8. Result of Pearson's Correlation Coefficient between Student Motivation and. Achievement.

\begin{tabular}{|c|c|c|c|c|c|c|c|c|c|c|}
\hline $\begin{array}{l}\text { Pearson's } \\
\text { Correlation } \\
\text { Coefficient }\end{array}$ & 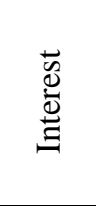 & 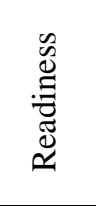 & $\frac{0}{0}$ & $\frac{\mathscr{d}}{0}$ & 菍 & $\begin{array}{l}\infty \\
0 \\
0\end{array}$ & & 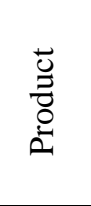 & $\begin{array}{l}\infty \\
\infty \\
\infty \\
\infty \\
\infty\end{array}$ & 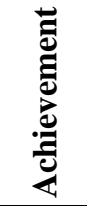 \\
\hline Interest & 1 & $.565^{* *}$ & $.662^{* *}$ & $.487^{* *}$ & $.625^{* *}$ & $.548^{* *}$ & $.405^{\text {** }}$ & $.574^{* *}$ & $.493^{* *}$ & -.021 \\
\hline Readiness & $.565^{* *}$ & 1 & $.641^{* *}$ & $.475^{* *}$ & $.568^{* *}$ & $.474^{* *}$ & $.326^{* * *}$ & $.527^{* *}$ & $.587^{* *}$ & $.214^{* *}$ \\
\hline LProfile & $.662^{* *}$ & $.641^{* *}$ & 1 & $.502^{* * *}$ & $.682^{* *}$ & $.615^{* *}$ & $.413^{* * *}$ & $.566^{* *}$ & $.646^{* *}$ & -.005 \\
\hline Troles & $.487^{* *}$ & $.475^{* *}$ & $.502^{* *}$ & 1 & $.484^{* *}$ & $.475^{* *}$ & $.401^{* *}$ & $.393^{* *}$ & $.492^{* * *}$ & .015 \\
\hline Content & $.625^{* *}$ & $.568^{* * *}$ & $.682^{* *}$ & $.484^{* * *}$ & 1 & $.573^{* *}$ & $.399^{* * *}$ & $.596^{* *}$ & $.533^{* *}$ & -.099 \\
\hline Process & $.548^{* *}$ & $.474^{* *}$ & $.615^{* *}$ & $.475^{* *}$ & $.573^{* *}$ & 1 & $.601^{* *}$ & $.617^{* *}$ & $.515^{* *}$ & -.041 \\
\hline Grouping & $.405^{* *}$ & $.326^{* * *}$ & $.413^{* *}$ & $.401^{* * *}$ & $.399^{* *}$ & $.601^{* * *}$ & 1 & $.435^{\text {** }}$ & $.409^{* *}$ & .041 \\
\hline Product & $.574^{* *}$ & $.527^{* * *}$ & $.566^{* *}$ & $.393^{* *}$ & $.596^{* *}$ & $.617^{* *}$ & $.435^{\text {** }}$ & 1 & $.595^{* *}$ & -.055 \\
\hline $\begin{array}{l}\text { Assess/ } \\
\text { Adjust }\end{array}$ & $.493^{* *}$ & $.587^{* *}$ & $.646^{* *}$ & $.492^{* * *}$ & $.533^{* *}$ & $.515^{* *}$ & $.409^{* *}$ & $.595^{* *}$ & 1 & -.097 \\
\hline Achievement & -.021 & $.214^{* *}$ & -.005 & .015 & -.099 & -.041 & .041 & -.055 & -.097 & 1 \\
\hline
\end{tabular}


**. Correlation is significant at the 0.01 level (2-tailed)

The Pearson's correlation coefficient analysis displayed in Table 4.3.4.4.1 above indicates that almost all of the MoDiELT constructs do not have significant relationship with student achievement, except Readiness. Although, Readiness has low significant correlation with student achievement, i.e. $\mathrm{r}=-2.14, \mathrm{p}<0.01$. Based on this finding, the researcher decided to reject his hypothesis and accepts the $\mathrm{H}_{0}$.

Therefore, the present study concludes that student motivation does not have a direct effect on student achievement. Nonetheless, detailed results that indicate high correlation within the MoDiELT constructs, reveal positive outcome of the practice of online differentiated instruction in English language teaching on student motivation. This finding is beneficial in making decision about planning a differentiated lesson through appropriate combination of differentiation constructs as listed below:

i. Interest and Readiness $(\mathrm{r}=.565, \mathrm{p}<0.01)$, Interest and LProfile $(\mathrm{r}=.662, \mathrm{p}<0.01)$, Interest and Content $(\mathrm{r}=.625, \mathrm{p}<0.01)$, Interest and Process $(\mathrm{r}=.548, \mathrm{p}<0.01)$, Interest and Product $(\mathrm{r}=.574, \mathrm{p}<0.01)$

ii. Readiness and LProfile $(\mathrm{r}=.641, \mathrm{p}<0.01)$, Readiness and Content $(\mathrm{r}=.568, \mathrm{p}<0.01)$, Readiness and Product $(\mathrm{r}=.527, \mathrm{p}<0.01)$, Readiness and Assess Adjustment $(\mathrm{r}=$ $.587, \mathrm{p}<0.01)$

iii. LProfile and Troles $(\mathrm{r}=.502, \mathrm{p}<0.01)$, LProfile and Content $(\mathrm{r}=.682, \mathrm{p}<0.01)$, LProfile and Process $(\mathrm{r}=.615, \mathrm{p}<0.01)$, LProfile and Product $(\mathrm{r}=.566, \mathrm{p}<0.01)$, LProfile and Assess Adjustment $(\mathrm{r}=.646, \mathrm{p}<0.01)$

iv. Content and Process $(\mathrm{r}=.573, \mathrm{p}<0.01)$, Content and Product $(\mathrm{r}=.596, \mathrm{p}<0.01)$, Content and Assess Adjustment $(\mathrm{r}=.533, \mathrm{p}<0.01)$

v. Process and Grouping $(\mathrm{r}=.601, \mathrm{p}<0.01)$, Process and Product $(\mathrm{r}=.617, \mathrm{p}<0.01)$, Process and Assess/Adjustment $(\mathrm{r}=.515, \mathrm{p}<0.01)$, and Product and Assess/Adjustment $(\mathrm{r}=.595, \mathrm{p}<0.01)$.

\section{Conclusion}

In brief, the quantitative measure employed to determine the influence of online differentiated instruction on student motivation and achievement reveals detailed account of which constructs of MoDiELT benefitted the students, and the extent to which these constructs were beneficial for the them. It was revealed that student motivation was prominently influenced by the constructs interest, learning profile, teacher's roles, content and product, suggesting that these were the most effective determinants that contribute to student motivation. Furthermore, it was also revealed that both Teacher 1 and Teacher 2 provided appropriate online differentiated English language teaching in terms of interest, learning profile, teacher's roles, and content whereas only Teacher 2 was deemed to have provided appropriate product differentiation. Thus, the researcher suggests that teachers should emphasize on these five constructs in planning for online differentiated English language lesson.

Based on all of the analyses on the students' scores on MoDiELT, it was found that the students were highly motivated toward online differentiated English language teaching, and their test scores were high. Detailed analyses indicate that the motivational construct teacher's roles contributes the most to student motivation, whereas only two constructs, i.e. readiness and learning profile, were found to be the predictors that significantly predict student achievement. Finally, although it was revealed that student motivation contributes to student achievement, the two variables however do not have any impact on one another. Thus, the present study establishes that there is no relationship between motivation and achievement in the context of online differentiated English language teaching. Nonetheless, it was found that only construct readiness has low significant correlation with student achievement. Although it is a low correlation, this suggests that readiness should be given the utmost consideration in preparing online differentiated English language lessons for gifted students. Meanwhile, the teachers 
should revisit their knowledge about instructional approach i.e. look back into their lesson planning with regards to other differentiated instruction strategies as revealed via the analysis of MoDiELT constructs.

Therefore, the quantitative findings highlight the mismatch between the teachers' practice of online differentiated instruction with regards to their students' motivation and achievement. To recap, even though the students' motivation and achievement were high, however, only five out of nine MoDiELT constructs, were proven to be significant to the students' learning outcomes. Meanwhile, teachers' practice of online differentiated instruction, motivation, and achievement are not significantly associated. This suggests that the students' learning outcomes are not exclusively influenced by the teachers' practice of online differentiated instruction. Based on this gap, this study thus establishes that teacher cognition of online differentiated instruction cannot be deemed as the main catalyst of successful English language teaching and learning especially during the pandemic outbreak.

Supplementary Materials: The instrument used in this study is a survey form called Motivational Orientation of Differentiated Instruction in English Language Teaching (MoDiELT). Information pertaining to the use of MoDiELT can be reached from the Correspondence* of this study.

Author Contributions: This study was made possible by the authors involved. Conceptualization, M.H.K.; Methodology, M.H.K.; Original Draft, M.H.K.; Reviewing \& Editing, M.M.Y., H.A., A.M.Z.; Supervision, M.M.Y., H.A., A.M.Z. All authors have read and agreed to the published version of the manuscript.

\section{Funding:}

Institutional Review Board Statement: Not applicable.

Informed Consent Statement: This study was made possible with informed consent from all the participants involved.

Data Availability Statement: Not applicable.

Conflicts of Interest: The authors declare no conflict of interest.

\section{References}

1. Abbati, D. G. 2012. Differentiated Instruction: Understanding the personal factors and organizational conditions that facilitate differentiated instruction in elementary mathematics classrooms. A dissertation submitted in partial satisfaction of the requirements for the degree of Doctor of Education in the Graduate Division of the University of California at Berkeley Committee.

2. Altintas, E. \& Özdemir, A. S. 2015. The Effect of the Developed Differentiation Approach on the Achievements of the Students. Eurasian Journal of Educational Research 61: 199-216.

3. Amadio, R. 2014. Differentiated Instruction in Secondary Mathematics. A Thesis Submitted to the Graduate Faculty In Partial Fulfillment Of the Requirements for the Degree Master of Science in Education University of Wisconsin.

4. Anderson, Kelly M.; Algozzine, Bob, E. 2007. Tips for Teaching: Differentiating Instruction to Include All Students. Preventing School Failure 51(3): 49-54.

5. Ann, E. \& Sizemore, K. 2015. A Phenomenological Study Of Differentiated Instruction.

6. Birello, M. 2012. Teacher Cognition and Language Teacher Education : beliefs and practice. A conversation with Simon Borg. Bellaterra Journal of Teaching \& Learning Language \& Literature 5(2): 88-94. doi:10.5565/253372

7. Blaz, D. 2013. Differentiated instruction: A guide for foreign language teachers. Routledge.

8. Borg, S. 1997. Unifying concepts in the study of teachers' cognitive structures.

9. Borg, S. 2003. Teacher cognition in language teaching: A review of research on what language teachers think, know, believe, and do. Language Teaching 36(2): 81-109. doi:10.1017/S0261444803001903

10. Borg, S. 2006. The distinctive characteristics of foreign language teachers. Language Teaching Research 1: 3-31.

11. Brulles, D. \& Winebrenner, S. 2012. Clustered for success. Educational Leadership 69(5): 41-45.

12. Caldwell, D. W. 2012. Educating Gifted Students in the Regular Classroom: Efficacy, Attitudes, and Differentiation of Instruction. 
Georgia Southern University. Retrieved from http://digitalcommons.georgiasouthern.edu/etd Recommended

13. Callahan, C. M., Tomlinson, C. A., Moon, T. R., Brighton, C. M. \& Hertberg, H. L. 2003. Lessons from ten years of research: Results from the National Research Center on the Gifted and Talented. Continuing Strand, Charlottesville, VA.

14. Chang, M. J. 1999. Does racial diversity matter? The educational impact of a racially diverse undergraduate population. Journal of College Student Development 40(4): 377-395.

15. Cifuentes, L. \& Ozel, S. 2006. Resources For Attending To The Needs Of Multicultural Learners. Knowledge Quest 35(2 (Nov./Dec. 2006)): 14-21.

16. Costa, A. \& Kallick, B. 2004. Assessment strategies for self-directed learning. doi:10.4135/9781483328782

17. Crocker, T. 2004. Underachievement: Is our vision too narrowed and blinkered? Fools step in where angelsfear to tread. Gifted 131: $10-14$.

18. Davis, G. A., Rimm, S. B. \& Siegle, D. 2011. Education of the Gifted and Talented. Education, hlm. 6th Edisi . Pearson.

19. Ellerbrock, R. S. 2011. Differentiated instruction in an inclusive 5th grade cotaught classroom (August).

20. Gault, S. T. 2009. Implementing differentiated instruction in third grade math classrooms. Walden University.

21. George, P. S. 2005. A rationale for differentiating instruction in the regular classroom. Theory into practice 44(3): 185-193.

22. Goodhew, G. 2009. Meeting the Needs of Gifted and Talented Students. London: Continuum International Publishing Group.

23. Gregorian, V. 2001. Teacher education must become colleges' preoccupation. Chronicle of Higher Education 17(B-7). doi:10.1017/cbo9781316152270.011

24. Hall, T. 2002. Differentiated Instruction. National Center on Accessing the General Curriculum ( .... Retrieved from http://www.principals.in/uploads/pdf/Instructional_Strategie/DI_Marching.pdf

25. Hogan, M. R. 2014. Differentiated instruction in a standards-based middle school science classroom. Walden University.

26. Hung, Y. 2015. Practice of Differentiated Instruction and Alternative Assessments with Young EFL Learners in Taiwan. TESOL International Journal 10(2): 48-63.

27. Hyde Kondor, A. C. 2007. One Size May Not Fit All, But the Right Teaching Strategies Might: The Effects of Differentiated Instruction on the Motivation of Talented and Gifted Students. Differentiation (June): 1-35.

28. Jin, E. A. W. N. 2015. Teachers ' Practices Of Using Differentiated Reading Instruction In Esl Classroom. Wawasan Open University.

29. Kamarulzaman, M. H., Azman, H. \& Zahidi, A. M. 2015. Differentiation Practices among the English Teachers at PERMATApintar National Gifted and Talented Center. Asian Social Science 11(9). doi:10.5539/ass.v11n9p346

30. Kauchak, D. P. \& Eggen, P. 2011. Introduction to Teaching: Becoming a Professional, hlm. 2nd Edisi . Upper Saddle River: Pearson Prentice Hall. Retrieved from http://books.google.com/books?id=V18zQQAACAAJ\&pgis=1

31. Kiley, D. 2011. Differentiated Instruction In The Secondary Classroom: Analysis Of The Level Of Implementation And Factors That Influence Practice.

32. Knowles, L. 2009. Differentiated Instruction in Reading: Easier than It Looks!, School Library Media Activities Monthly, 2009Jan. School Library Media Activities Monthly 25(5): 26. Retrieved from https://eric.ed.gov/?id=EJ820268

33. Launder, B. L. 2011. Supporting gifted students in the regular education elementary classroom through differentiated instruction. Bowling Green State University.

34. Lawrence-Brown, D. 2004. Differentiated Instruction: Inclusive Strategies For Standards-Based Learning That Benefit The Whole Class. American Secondary Education 32(3): 34-62. Retrieved from http://web.b.ebscohost.com/ehost/pdfviewer/pdfviewer?sid=def73189-e639-40df-85ff9f9b6a621bc1\%40sessionmgr101\&vid=3\&hid=123

35. Lee, V. E. 2001. Restructuring high schools for equity and excellence: What works.

36. Levy, H. M. 2008. Meeting the needs of all students through differentiated instruction: Helping every child reach and exceed standards. The Clearing House: A Journal of Educational Strategies, Issues and Ideas 81(4): 161-164.

37. Loeser, J. W. 2014. Differentiated Instruction. Research Starters Education 1.

38. Maddox, C. \& Maddox, C. 2015. Elementary ( K-5 ) Teachers ' Perceptions of Differentiated Instruction This is to certify that the 
doctoral dissertation by.

39. Malaysia, M. of E. 2013. Malaysia Education Blueprint 2013 - 2025 (Preschool to Post-Secondary Education). Education, hlm. Vol. 27. Kementerian Pendidikan Malaysia. doi:10.1016/j.tate.2010.08.007

40. Marotta-Garcia, C. 2011. Teachers Use Of A Differentiated Curriculum For Gifted Students. University Of Southern California.

41. Martin, M. \& Pickett, M. 2013. The Effects of Differentiated Instruction on Motivation and Engagement in Fifth-Grade Gifted Math and Music Students. Online Submission. Saint Xavier University.

42. McCoy, K. M. \& Radar, M. H. 2007. Differentiated instruction in the classroom and technology lab: Back to the one-room schoolhouse. Journal of Applied Research for Business Instruction 5(1): 1-6.

43. Powers, E. A. 2008. The Use of Independent Study as a Viable Differentiation Technique for Gifted Learners in the Regular Classroom. Gifted Child Today 31(3): 57-65. doi:10.4219/gct-2008-786

44. Robinson, L., Maldonado, N. \& Whaley, J. 2014. Perceptions about Implementation of Differentiated Instruction. Edric 1-22. Retrieved from http://files.eric.ed.gov/fulltext/ED554312.pdf

45. Rock, M. L., Gregg, M., Ellis, E. \& Gable, R. A. 2008. REACH: A framework for differentiating classroom instruction. Preventing School Failure: Alternative Education for Children and Youth 52(2): 31-47.

46. Rodriguez, A. 2012. An analysis of elementary school teachers' knowledge and use of differentiated instruction.

47. Ruggiero, M. J. 2012. Effects of Gifted and Talented Programs on Standardized Test Scores of Fourth Grade Students in Two School Districts. State University of New York.

48. Sabb-cordes, M. L. 2016. Teachers' Perceptions of Differentiated Learning for At-Risk Second-Grade Students in Reading. Walden University.

49. Santamaria, L. J. 2009. Culturally Responsive Differentiated Instruction: Narrowing Gaps Between Best Pedagogical Practices Benefiting All Learners. Teachers College Record 111(1): 214-247. doi:10.1111/j.1467-9620.2004.00328.x

50. Savage, M. 2011. Exploring the relationship between differentiated instruction and student performance. East Carolina University.

51. Tieso, C. 2005. The effects of grouping practices and curricular adjustments on achievement. Journal for the Education of the Gifted 29(1): 60-89.

52. Tomlinson, C. 2005. This Issue: Differentiated Instruction. Theory Into Practice 44(3): 183-184. doi:10.1207/s15430421tip4403_1

53. Tomlinson, C. A. 1995. Differentiating Instruction for Advanced Learners in the Mixed-Ability Middle School Classroom. ERIC Digest E536.

54. Tomlinson, C. A. 1999. Mapping a route toward differentiated instruction. Educational leadership 57: $12-17$.

55. Tomlinson, C. A. 2000. Differentiation of Instruction in the Elementary Grades. ERIC Digests 1-7.

56. Tomlinson, C. A. 2008. Goalsof Differentiation. Educational Leadership.

57. Tomlinson, C. A. \& Allan, S. 2000. Leadership for differentiating schools \& classrooms.

58. Tomlinson, C. A. \& Kalbfleisch, M. I. 1998. Teach Me, Teach My Brain: A Call for Differentiated Classrooms. Educational Leadership 56(3): 52-55. Retrieved from http://web.ebscohost.com.ezproxy.mtsu.edu/ehost/pdfviewer/pdfviewer?sid=dc1003de78b2-4562-9f4f-

86a591997879@sessionmgr12\&vid=11\&hid=21\%5Cnhttp://www.eric.ed.gov/ERICWebPortal/recordDetail?accno=EJ575232

59. Tomlinson, C. A. \& Strickland, C. A. 2005. Differentiation in practice: A resource guide for differentiating curriculum, grades 9-12. ASCD.

60. Tramonto, S. A. 2013. Differentiation in the Elementary School Reading Program and Student Achievement. State University of New York. Retrieved from http://digitalcommons.brockport.edu/ehd_theses

61. Valiande, S. \& Koutselini, M. I. 2009. Application and evaluation of differentiation instruction in mixed ability classrooms. 4th Hellenic Observatory PhD Symposium, London, LSE, hlm. 25-26.

62. VanSciver, J. H. 2005. NCLB fitfully fits differentiated instruction. The Education Digest 70(9): 37.

63. VanTassel-Baska, J. \& Johnsen, S. 2007. Teacher Education Standards for the Field of Gifted EducationA Vision of Coherence for Personnel Preparation in the 21st Century. Gifted Child Quarterly - GIFTED CHILD QUART, hlm. Vol. 51. doi:10.1177/0016986207299880 
64. Vidergor, H. 2010. Teachers Of The Gifted In Israel: Cognitive Aspects Of Teachers' Professional Development Programs. University of Haifa.

65. Wan, S. W.-Y. 2015. Differentiated instruction: Hong Kong prospective teachers' teaching efficacy and beliefs. Teachers and Teaching 22(2): 148-176. doi:10.1080/13540602.2015.1055435

66. Weibell, C. J. 2011. Principles of learning: A conceptual framework for domain-specific theories of learning. Retrieved from http://scholarsarchive.byu.edu/etd/2759/

67. White, S. E. 2013. Differentiating Instruction for Gifted Learners in the Regular Classroom: A Quick-Reference Guide for Teachers.

68. Williams, K. G. 2012. The Effect Of Differentiated Instruction On Standardized.

69. Yassin, S. F. M., Ishak, N. M., Yunus, M. M. \& Majid, R. A. 2012. The Identification of Gifted and Talented Students. Procedia Social and Behavioral Sciences 55: 585-593. doi:10.1016/j.sbspro.2012.09.540

70. Yunus, M. M., Sulaiman, N. A. \& Embi, M. A. 2013. Malaysian gifted students' use of English language learning strategies. English Language Teaching 6(4): 97-109. doi:10.5539/elt.v6n4p97 